\title{
Mutagenesis and screening of Penicillium oxalicum (Dal 5) for enhancing cellulase production
}

\author{
Ankita Singh ${ }^{1}$, B. S. Chadha ${ }^{2, *}$ \\ ${ }^{1}$ Senior Resident, ${ }^{2}$ Professor, Dept. of Microbiology, Pandit Jawahar Lal Nehru Government Medical College \& Hospital, \\ Chamba, Himachal Pradesh, ${ }^{2}$ Guru Nanak Dev University, Amritsar, Punjab, India
}

*Corresponding Author:

Email: singhankitahp5@gmail.com

\begin{abstract}
In the modern era due to increasing fuel demand, prices of crude oil is increasing day by days. So the need for bioenergy sources is increasing in coming years. Of all the biomass present in the world lignocelluloses as industrial, forest and agricultural residues constitutes the major portion. The present study was focused to determine potential of fungus Penicillium oxalicum (Dal 5) for cellulase production on different commonly available lignocellulosic substrates (Rice straw, Wheat straw, Corn cob, Baggase, Sorghum straw), organic nitrogen source (Corn steep liquor).
\end{abstract}

Keywords: Bioenergy, Buffer, Cellulase, Enzyme, Substrate.

\section{Introduction}

Rising prices of crude oil is increasing day by day due to increase in fuel demand so the alternative source of bioenergy is increasing sharply. So lignocelluloses is identified as the prime source of biofuel and other valuable products. Lignocelluloses is agricultural, industrial and forest contributes to the majority of biomass in the world (Howard et al., 2003). For the production of industrial important products from lignocellulosic biomass, bioconverstion of cellulosic and hemicellulolytic components is necessary into fermentable sugars. So variety of microorganisums bacteria and fungi has the ability to degrade the lignocellulosic biomass to glucose and xylose monomers. Some cellulases exist as discreate multienzyme complexes, called cellulosomes which consists of multiple subunits cellulolytic enzymes on the other hand of filamentous fungi is non-complexed that consists of exoglucanases or cellobiohydrolases (CBH I and CBH II). Enzymes synergistically act to catalyze the hydrolysis of cellulose (Wen et al., 2005). Cellulose units are interlinked by $\beta-1,4$-glycosidic bonds is a liner polymer of D-glucose units, which is renewable biomass available on earth.

1. Endoglucanase (EC 3.2.1.74) which attack cellulose in amorphous zone and release oligomers.

2. Cellobiohydrolase (EC 3.2.1.91) that liberate cellobiose from reducing and non-reducing ends.

3. $\beta$-Gucosidase (EC 3.2.1.21) which hydrolyse cellobiose to glucose.

Cellulose In plant cell walls, is entangled with and shielded by hemicellulose, is group of complex polysaccharides composed of different glyco-units and glycosidic bonds. Degradation of hemicellulose, converts hemicellulose into valuable saccharides, is done by interdependent and synergistic hemicellulases. Xylan, $\beta$-glucan, polygalacturonan, xyloglucan, arabinoxylan, mannan, galactan, galactomannan, arabinan, etc are comman hemiicelluloses, they are targets of xylanase, $\beta$-glucanase, polygalacturonase, xyloglucanase, mannanase, arabinase, galactanase, glucuronidase, acetyl xylan esterase, and other enzymes (Wen et al., 2005).

Temperature, $\mathrm{pH}$, adsorption are physical parameters, nitrogen, phosphorus, chemical factors phenolic compounds and some inhibitors can inhibit bioconversion of lignocellulose. Cellulases production by microbial cells is done by genetic and biochemical which also includes catabolite repression, induction, or end product inhibition (Cheng et al., 2009). Many efforts made to increase the production of cellulases through strain improvement by mutagenesis (Kaur et al., 2012). Mutagenized and genetically modified organism produces high levels of cellulases (Mandel and Andreotti 1978; Nevalainen, 1980; Durand, 1988; Szengyel, 2000). The objective of these efforts has been to obtain high levels of cellulases in order to degrade waste cellulose. However, despite the effort of many laboratories, only few commercially efficient enzyme complexes have been produced. To resolve problems, of high cost of enzymes production many researches are done in isolating new microorganisums for production of higher specific activity and greater efficiency (Stahlberg 1991). The present study was focussed to determine potential of fungus Penicillium oxalicum (Dal 5) for cellulase substrates of lignocellulosic (Rice straw, Baggase, Wheat straw, Sorghum straw, Corn cob), organic nitrogen source (Corn steep liquor).

\section{Materials and Methods}

\subsection{Microorganisms and culture media}

Penicillium oxalicum (Dal 5) wild type strain and mutants were maintained on YpSS medium of following composition. 


\begin{tabular}{|l|c|}
\hline \multicolumn{1}{|c|}{ YpSS (pH 6.0) } & Composition (\%) \\
\hline Soluble starch & 1.5 \\
\hline Yeast extract & 0.4 \\
\hline $\mathrm{KH}_{2} \mathrm{PO}_{4}$ & 0.2 \\
\hline $\mathrm{K}_{2} \mathrm{HPO}_{4}$ & 0.23 \\
\hline $\mathrm{MgSO}_{4}$ & 0.05 \\
\hline Citric acid & 0.057 \\
\hline
\end{tabular}

\subsection{Slide culturing for morphological/microscopic examination}

A sheet of sterile filter paper along with U-shaped glass rods were placed at the bottom of petridish. The filter paper was moistened with sterile distilled water. A glass slide was placed on the glass rods along with cover slips. The entire assembly was autoclaved. A 5 $\mathrm{mm}$ thin agar block (YpSS) was placed on the slides asceptically using forceps. The block was inoculated with spores of P.oxallicum and cover slip was placed over it. After that the assembly was incubated at $30^{\circ} \mathrm{C}$ for $48 \mathrm{~h}$. Then the slide was observed under microscope $(10 \mathrm{X})$ and $(40 \mathrm{X})$ to examine mycelial growth as well as sporulation.

2.3 Cultures are screened for production of hemicellulase/cellulase different organic nitrogen sources and lignocelluloses sources

Cellulase/hemicellulase prduction is studied by shake flask culture of P.oxalicum. The cellulase production medium $50 \mathrm{ml}$ in $250 \mathrm{ml}$ Erlenmeyer flasks contained (\% w/v) of:-

Cellulose powder: $3 \%$

Rice straw: $1 \%$

Wheat bran: $1 \%$

$\mathrm{KH}_{2} \mathrm{PO}_{4}: 2.4 \%$

$\left(\mathrm{NH}_{4}\right)_{2} \mathrm{SO}_{4}: 0.5 \%$

$\mathrm{MgSO}_{4}: 0.12 \%$

Tween 80: 0.1\%

Trace elements

$\mathrm{CuSO}_{4}: 100 \mathrm{mg} / 10 \mathrm{ml}$

$\mathrm{MnSO}_{4}: 100 \mathrm{mg} / 10 \mathrm{ml}$

$\mathrm{ZnSO}_{4}: 100 \mathrm{mg} / \mathrm{ml}$

Filter sterilized $0.4 \%$ urea was added after autoclaving.

To study the effect of different carbon sources, rice straw in the medium was replaced with either of sorghum straw, baggase, wheat bran, wheat straw or corn cob. Furthermore the effect of adding CSL in place of $\left(\mathrm{NH}_{4}\right)_{2} \mathrm{SO}_{4}$ in enzyme production was also studied.

Production medium was inoculated with 4 stubs of actively growing P.oxalicum culture taken from the petriplate and incubated for 7 days at $30^{\circ} \mathrm{C}$. After 7 days contents of flasks were centrifuged at 10,000 rpm for $10 \mathrm{~min}$. Then supernatent was taken and pellet was discarded. The enzyme extract was suitably diluted (2, $5,10,20,50$ and $100 \mathrm{X}$ ) using sodium acetate buffer (50mM, pH 5.0).
2.4 Estimation of enzyme activities on different carbon sources and organic nitrogen sources:

1. Activity of $\beta$ - Glucosidase:

Substrate: In $50 \mathrm{mM}$ sodium acetate buffer of $\mathrm{pH}$ 5.0, 4 nitrophenyl $\beta$-D glucopyranoside (pNPG) $(3 \mathrm{mM})$ is prepared.

The enzyme assay was performed using micro titre plate method. The reagent blank contained buffer $(100 \mu \mathrm{l})$ whereas the substrate blank contained pNPG $(25 \mu \mathrm{l})$ and buffer $(75 \mu \mathrm{l})$. The enzyme blank was prepared by adding buffer $(75 \mu \mathrm{l})$ and diluted enzyme $(25 \mu 1)$. The reaction mixture contained buffer $(50 \mu 1)$, suitably diluted enzyme $(25 \mu 1)$, and substrate $(25 \mu \mathrm{l})$. The ELISA plate was wrapped in foil and incubated $50^{\circ} \mathrm{C}$ for $30 \mathrm{~min}$. The reaction was stopped by adding $\mathrm{NaOH}$ glycine buffer $100 \mu 1$. The developed yellow color was read using microplate reader at $405 \mathrm{~nm}$ (BIORAD plate reader). The amount of $p$-nitrophenol released was quantified using the pNP standard. The amount of enzyme required to release $1 \mu 1$ of pNP per min The $\beta$-glucosidase activity (units $/ \mathrm{ml}$ ) and was expressed under assay conditions.

2. Cellobiosidase activity (CBH I+ CBH II)

Substrate: 4 nitrophenyl $\beta$-D-cellobioside prepared in sodium acetate buffer pH.5.0.

The enzyme assay was performed using micro titre plate method .The reagent blank contained buffer $(100 \mu \mathrm{l})$ whereas, the substrate blank contained pNPG $(25 \mu 1)$ and buffer $(75 \mu l)$. The enzyme blank was prepared by adding buffer $(75 \mu 1)$ and diluted enzyme $(25 \mu 1)$. The reaction mixture contained buffer $(50 \mu 1)$, suitably diluted enzyme $(25 \mu \mathrm{l})$, and substrate $(25 \mu 1)$. The ELISA plate was wrapped in foil and is incubated for $30 \mathrm{~min}$ at 50 degree temprature. $\mathrm{NaOH}$ glycine buffer $100 \mu$ is added to stop the reaction. The developed yellow color was read using microplate reader at $405 \mathrm{~nm}$ (BIORAD plate reader). The amount of $p$-nitrophenol released was quantified using the pNP standard. The amount of enzyme required to release $1 \mu 1$ of pNP per min under assay conditions.

3. Cellobiohydrolase activity

Substrate: 4 nitrophenyl $\beta$-D-lactopyranoside (pNPL $3 \mathrm{mM}$ ) prepared in sodium acetate buffer $\mathrm{pH}$ 5.0.The enzyme assay was performed using micro titre plate method. Buffer $(100 \mu \mathrm{l})$ is reagent blank, pNPL $(25 \mu \mathrm{l})$ and buffer $(75 \mu \mathrm{l})$ is substrate blank. The enzyme blank contained buffer $(75 \mu \mathrm{l})$ and enzyme $(25 \mu 1)$.The reaction mixture contained buffer $(50 \mu 1)$, enzyme $(25 \mu \mathrm{l})$, and substrate $(25 \mu \mathrm{l})$. The ELISA plate was wrapped in foil and incubated $50^{\circ} \mathrm{C}$ for $1 \mathrm{~h}$. The reaction was stopped by adding $\mathrm{NaOH}$ glycine buffer $100 \mu$. The developed yellow color was read using microplate reader at $405 \mathrm{~nm}$ (BIORAD plate reader). The 
amount of p-nitrophenol released was quantified using the pNP standard. The cellobiohydrolase activity amount of enzyme required to release $1 \mu 1$ of pNP per min under assay conditions

4. $\beta$-Xylosidase activity

Substrate: 4 nitrophenyl $\beta$-D-Xyloside prepared in sodium acetate buffer $\mathrm{pH}$ 5.0.

The enzyme assay was performed using micro titre plate method. The reagent blank contained buffer $(100 \mu \mathrm{l})$ whereas the substrate blank contained pNPG $(25 \mu \mathrm{l})$ and buffer $(75 \mu \mathrm{l})$. The enzyme blank was prepared by adding buffer $(75 \mu \mathrm{l})$ and diluted enzyme $(25 \mu 1)$. The reaction mixture contained buffer $(50 \mu 1)$, suitably diluted enzyme $(25 \mu 1)$, and substrate $(25 \mu 1)$. The ELISA plate was wrapped in foil and incubation is done for $30 \mathrm{~min}$ under $50^{\circ} \mathrm{C}$. stop reaction by adding $\mathrm{NaOH}$ glycine buffer $100 \mu 1$. The developed yellow color was read using microplate reader at $405 \mathrm{~nm}$ (BIORAD plate reader). The amount of $p$-nitrophenol released was quantified using the pNP standard. The xyloside activity was expressed as the amount of enzyme required to release $1 \mu \mathrm{l}$ of $\mathrm{pNP}$ per min under assay conditions.

5. Arabinofuranosidase activity

Substrate: 4 nitrophenyl $\alpha$-L-Arabinofuranoside prepared in acetate buffer $\mathrm{pH} .5$

The enzyme assay was performed using micro titre plate method. The reagent blank contained buffer $(100 \mu \mathrm{l})$ whereas, the substrate blank contained pNPG $(25 \mu 1)$ and buffer $(75 \mu 1)$. The enzyme blank was prepared by adding buffer $(75 \mu \mathrm{l})$ and diluted enzyme $(25 \mu l)$. The reaction mixture contained buffer $(50 \mu l)$ suitably diluted enzyme $(25 \mu 1)$ and substrate $(25 \mu 1)$. The ELISA plate was wrapped in foil and incubated $50^{\circ} \mathrm{C}$ for $30 \mathrm{~min}$. The reaction was stopped by adding $\mathrm{NaOH}$ glycine buffer $100 \mu 1$. The developed yellow color read by microplate reader at $405 \mathrm{~nm}$ (BIORAD plate reader). The amount of $p$-nitrophenol released was quantified using the pNP standard. The arabinofuranoside activity was expressed as the amount of enzyme required to release $1 \mu \mathrm{l}$ of $\mathrm{pNP}$ per min under assay conditions.

6. Endoglucanase activity (EG)

Substrate: $1 \%$ CMC prepared in sodium citrate buffer.

CMC substrate measures The endoglucanase activity. The reaction was initiated by incubating $500 \mu \mathrm{l}$ of substrate $(1 \%$ CMC prepared in $\mathrm{pH} 5.0$, $50 \mathrm{mM}$ acetate buffer) and diluted enzyme of $500 \mu \mathrm{l}$. Suitable enzyme blank that contained $500 \mu \mathrm{l}$ of enzyme and $500 \mu \mathrm{l}$ of buffer while substrate blank that contained $500 \mu \mathrm{l}$ of substrate and $500 \mu \mathrm{l}$ of buffer were also included. The reaction was carried out for $10 \mathrm{~min}$ at $50^{\circ} \mathrm{C} .3 \mathrm{ml}$ of dinitrosalicylic acid (DNS) is used for stoping the reaction followed by boiling at $100^{\circ} \mathrm{C}$ for $10 \mathrm{~min}$.The developed colour was read at 540nm using NOVO spec 2 spectrophotometer .The amount of released sugars was quantified using glucose standard. Endoglucanase (CM Case) activity of one unit defined as $1 \mu \mathrm{lmol}$ of glucose equivalent liberated per unit under assay condition.

\section{Fpase activity}

Substrate: Whatman No. 1 filter paper.

The reaction mixture contained $(500 \mu 1)$ buffer $(500 \mu 1)$ suitably diluted enzyme and one properly folded filter paper strip. The blank contained buffer $1000 \mu \mathrm{l}$ whereas the substrate blank contained sodium citrate $1000 \mu \mathrm{l}$ buffer and paper strip (1* $6 \mathrm{~mm})$ properly folded. Incubated at $50^{\circ} \mathrm{C}$ for 60 min. $3 \mathrm{ml}$ of dinitrosalicylic acid (DNS) was added to stop the reaction followed by boiling at $100^{\circ} \mathrm{C}$ for $10 \mathrm{~min}$. The developed color was read at 540nm using NOVO spec II spectrophotometer. The amount released sugars was estimated using glucose standard.

8. Xylanase activity

Substrate: Sodium citrate buffer is prepared in $1 \%$ Birchwood xylan. Mixture of reaction contains $(500 \mu 1)$ substrate and $(500 \mu 1)$ dilute enzyme. Buffer contains reagent blank $1000 \mu l$ whereas the substrate blank contained $(500 \mu 1)$ xylan and $(500 \mu 1)$ buffer .The enzyme blank was constituted by adding $(500 \mu 1)$ enzyme and $500 \mu \mathrm{l}$ buffer this was then incubated for $10 \mathrm{~min}$ at $50^{\circ} \mathrm{C}$ temperature. The reaction was stopped by adding $3 \mathrm{ml}$ of dinitrosalicylic acid (DNS) followed by boiling at $100^{\circ} \mathrm{C}$ for $10 \mathrm{~min}$. The developed color was read at $540 \mathrm{~nm}$ using NOVO spec II spectrophotometer. The amount of released sugars was quantified using glucose standard. One unit of xylanase activity was defined as $1 \mu \mathrm{l} \mathrm{mol}$ of glucose equivalent liberated per unit under assay condition

\section{Results and Discussion}

3.1 Morphological and microscopic characterization

The culture up on grown on YpSS agar produced sporulating colonies which were velvety in texture and blue-green in color. Light microscopy revealed elliptical conidia produced on smooth-walled conidiophores. Microscopic view also showed branched conidiophores bearing phialides in clusters (brush like structure) which had chains of conidia. The conidiophores showed divaricate branching pattern (Fig. 4).

\subsection{Carbon sources effects on cellulase/hemicellulase production.}

The results in Table 1 shows that cellobiohydrolase activity $(\mathrm{CBH})$ as measured against pNPL was maximally produced $(0.34$ units $/ \mathrm{ml})$ when rice straw, 
sorghum straw or wheat straw was used as carbon source (Fig. 5). The cellobiosidase activity (Fig. 6) against pNPC which corresponds to sum total of CBH I, $\mathrm{CBH}$ II and EG 7 was again maximally supported by rice straw (1.4 units/ml) followed by baggase (1.17 units /ml). Recombinent DNA techonology can be used to understand moleculer mechanisum which can help in biodegradation of lignocelluloses.

Table 1: carbon sources effects at cellulase production by $P$.oxalicum (Dal5)

\begin{tabular}{|l|c|c|c|c|c|}
\hline & $\begin{array}{c}\text { CBH } \\
\text { (units/ml) }\end{array}$ & $\begin{array}{c}\text { Cellobiosidase } \\
\text { (units/ml) }\end{array}$ & $\begin{array}{c}\boldsymbol{\beta} \text {-glucosidase } \\
\text { (units/ml) }\end{array}$ & $\begin{array}{c}\text { CMCase } \\
\text { (units/ml/) }\end{array}$ & $\begin{array}{c}\text { Fpase } \\
\text { (units/ml) }\end{array}$ \\
\hline Rice straw & 0.34 & 1.41 & 2.74 & 17.17 & 0.81 \\
\hline Baggase & 0.23 & 1.17 & 2.76 & 17.45 & 0.60 \\
\hline Corn -cob & 0.24 & 0.80 & 1.62 & 18.50 & 0.77 \\
\hline $\begin{array}{l}\text { Sorghum } \\
\text { straw }\end{array}$ & 0.34 & 0.92 & 1.37 & 19.81 & 0.73 \\
\hline $\begin{array}{l}\text { Wheat } \\
\text { straw }\end{array}$ & 0.34 & 0.85 & 1.74 & 19.44 & 0.60 \\
\hline
\end{tabular}

The $\beta$ - glucosidase activity measured against pNPG as substrate was maximal (2.76 units/ml) when baggase was used as carbon. Rice straw also supported high $\beta$ glucosidase activity (2.74 units/ml) (Fig. 7). The Endoglucanase activity as measured against $1 \% \mathrm{CMC}$ was produced maximally (19.8 units/ml) in presence of sorghum straw as carbon source followed by wheat straw (19.44 units/ml) (Fig. 8). The total cellulase activity as measured against Whatman No. 1 filter paper was highest $(0.80$ units $/ \mathrm{ml})$ in presence of rice straw.

The results in Table 2, shows that the xylanase activity as measured against $1 \%$ Birch wood xylan was maximal (92.50 units/ml) when wheat straw was used as carbon source whereas, in presence of corn cob the culture produced (91.21 units/ml) of xylanases (Fig. 10).

Table 2: Effect of Carbon sources on hemicellulase production

\begin{tabular}{|l|c|c|c|}
\hline & $\begin{array}{c}\text { Xylanase } \\
(\mathbf{u n i t s} / \mathbf{m l})\end{array}$ & $\begin{array}{c}\boldsymbol{\beta} \text {-Xylosidase } \\
(\mathbf{u n i t s} / \mathbf{m l})\end{array}$ & $\begin{array}{c}\text { Arabinofuranosidase } \\
\text { (units/ml) }\end{array}$ \\
\hline $\begin{array}{l}\text { 1. Rice -straw } \\
\text { (control) }\end{array}$ & 61.05 & 0.07 & 0.09 \\
\hline 2. Baggase & 56.76 & 0.06 & 0.20 \\
\hline 3. Corn -cob & 91.21 & 0.07 & 0.11 \\
\hline $\begin{array}{l}\text { 4. Sorghum } \\
\text { straw }\end{array}$ & 88.19 & 0.10 & 0.08 \\
\hline 5. Wheat straw & 92.50 & 0.08 & 0.12 \\
\hline
\end{tabular}

The $\beta$-Xylosidase activity as measured against pNP X was maximally produced (o.11units/ml) when Sorghum straw was used as carbon sources followed by $(0.08$ units $/ \mathrm{ml})$ in presence of wheat straw as carbon source in (Fig. 11). The arabinofuranosidase activity was measured against $\alpha-\mathrm{L}$ arabinofuranoside was maximal (0.19 units/ml) when wheat straw was used as carbon source in (Fig. 12) when baggase was used as carbon source followed by (0.12 units/ml).

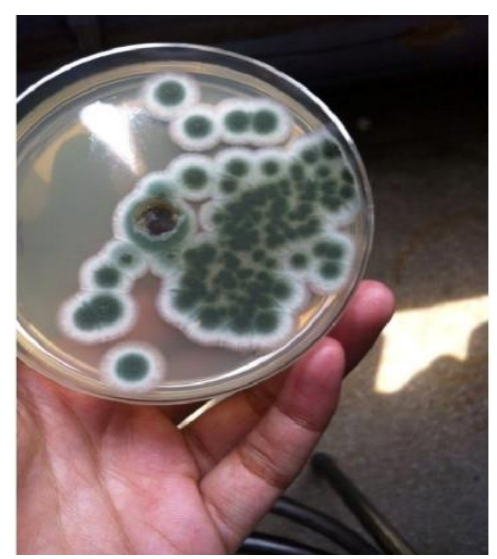

Fig. 2: Petriplate containing P. oxalicum (Dal 5) culture 


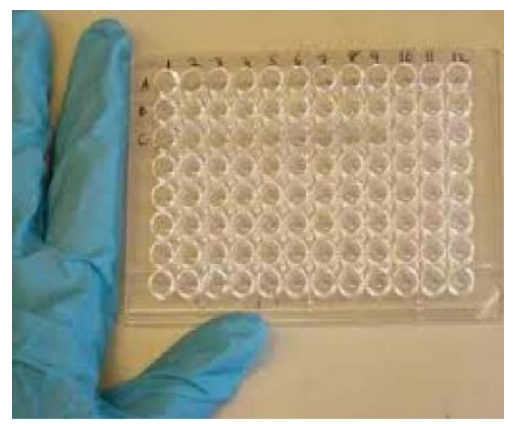

a

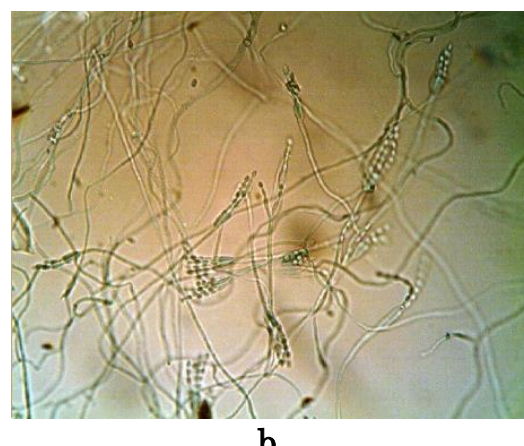

b

Fig. 3: a: Well Microtitreplate; b: P. oxalicum (Dal 5) slide culture stained with lactophenol observed under microscope (40X)

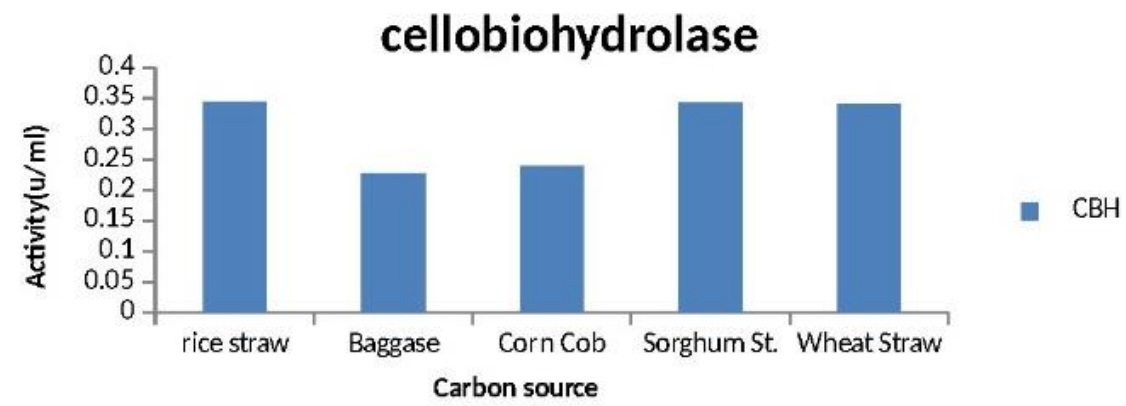

a

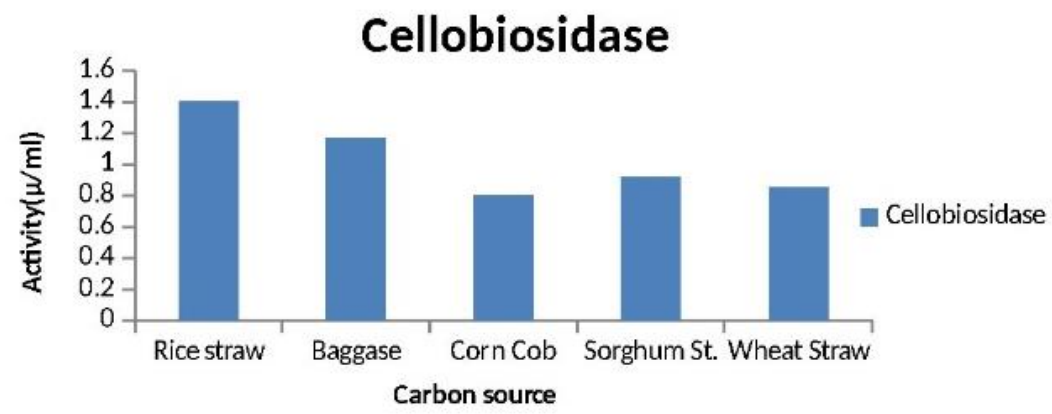

b

Fig. 4: a: Cellobiohydrolase activity produced by $\mathrm{P}$. oxalicum (Dal 5) in presence of different carbon sources; b: Cellobiosidase activity produced by $\mathrm{P}$. oxalicum (Dal 5) in presence of different carbon sources

\section{$\beta$ - Glucosidase}

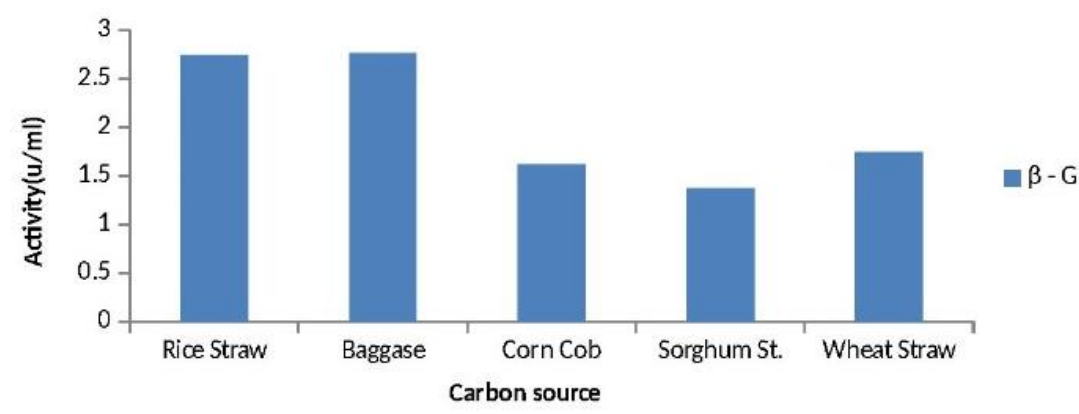

a 


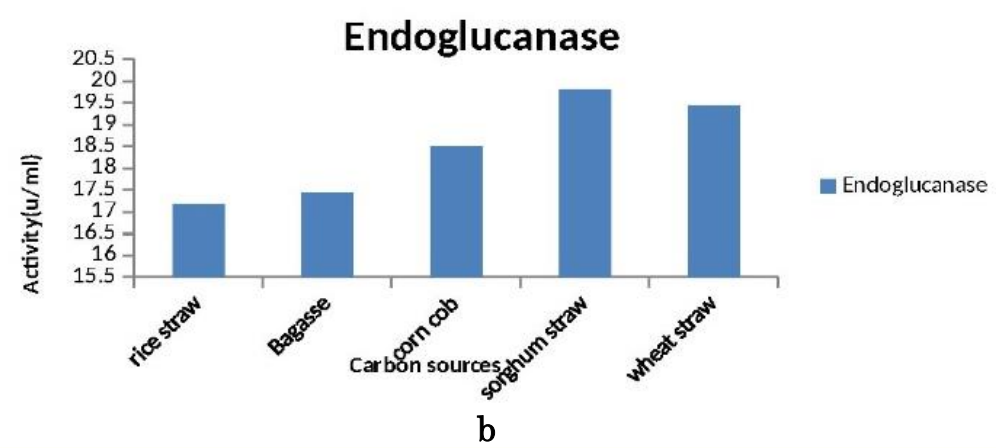

Fig. 5: a: $\beta$-Glucosidase activity produced by $P$. oxalicum (Dal5) in presence of different carbon sources; b: Endoglucanase activity by P. oxalicum (Dal5) in presence of different carbon sources

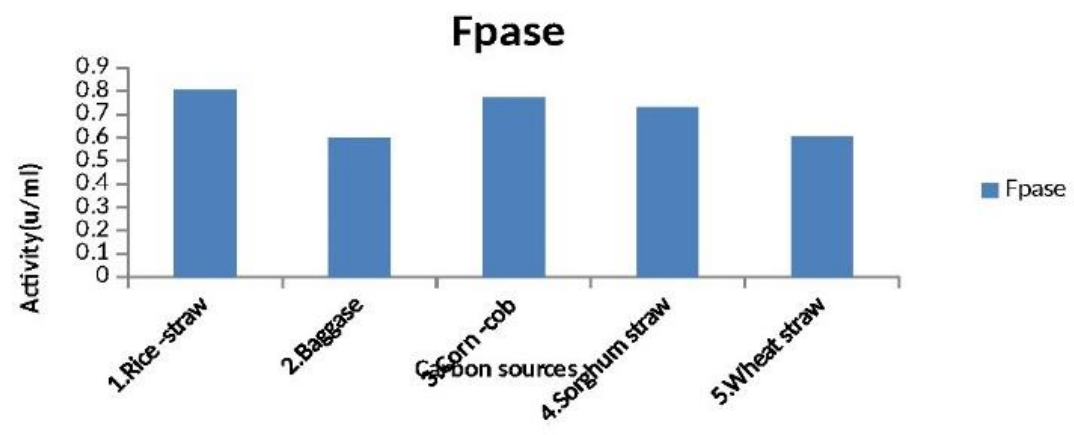

a

\section{Xylanase}

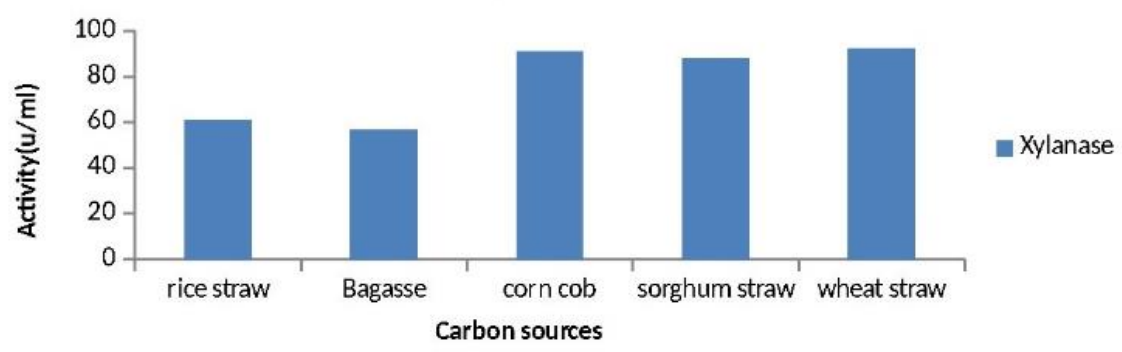

b

Fig. 6: a: Filter paper activity by $P$. oxalicum (Dal5) in presence of different carbon sources; b: Xylanase activity by $P$. oxalicum (Dal5) in presence of different carbon sources

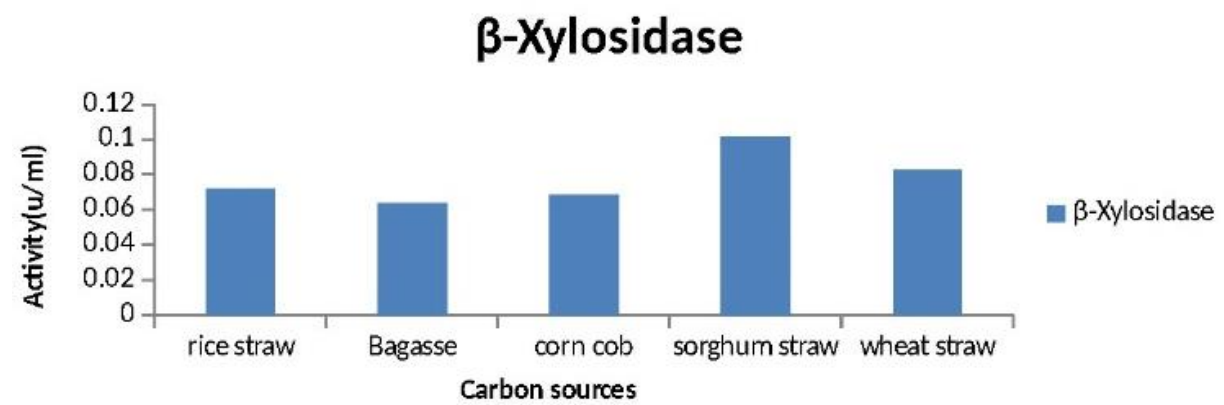

a 


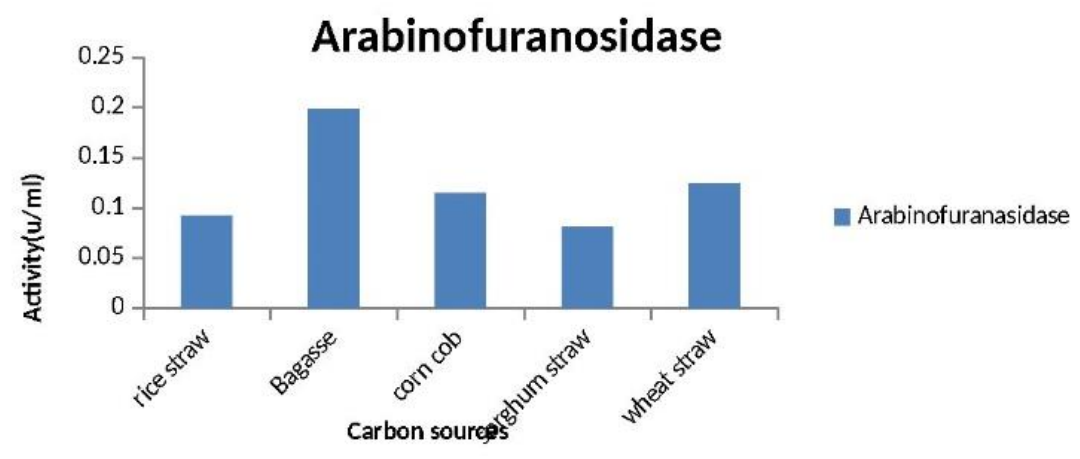

b

Fig. 7: a: $\beta$-Xylosidase activity by $P$. oxalicum (Dal5) in presence of different carbon sources; b: Afase activity by $P$. oxalicum (Dal5) in presence of different carbon sources

\section{Conclusion}

The present study was focussed to determine potential of fungus Penicillium oxalicum (Dal 5) for cellulase production on lignocellulosic substrates ( Corn cob, Wheat straw, Rice straw, Sorghum straw, Baggase), organic nitrogen source (Corn steep liquor).

\section{References}

1. Howard RC, Abotsi E, Jansen van Rensberg EL and Howard S, Lignucellulosic biotechonlogy issues of bioconversion and enzyme production, Afr J Biotechol, 2(2003) 602-19.

2. Wen $\mathrm{Z}$ et al. Production of cellulose by Trichoderma reesei from dairy manure.bioresour technol.2005;96:491-9.

3. Chang et al. isolation of cellulose-hydrolytic bacteria and applications of the cellulolytic enzymes for cellulosic biohydrogen production. Enzyme Microb Technol.2009;44:417-25.

4. Kaur et al. Isolation and screening of cellulose producing microorganisms from degraded wood.IJPBSF. 2012;2(1):10-5

5. Mandel M and Andreotti RE. problems and challenges in the cellulose to cellulose fermentation .Process Biochem.1978:13:6-13.

6. Nevalainen et al. A high cellulose producing mutant strain to Trichoderma reesei. Enzyme and microbial technology.1980;2(1):59-60.

7. Durand et al. genetic improvement of Trichoderma reesei for earge scale cellulase production. Enzyme and Microbial Technology.1988;10:341-6.

8. Szengyel $\mathrm{Z}$ et al. cellulase production of Trichoderma Reesei Rut C 30 using steam -pretreated spruce .hydrolytic potential of cellulases on different substrates .App I Biochem Biotechnol .2000;8486:679-91.

How to cite this article: S. Ankita, Chadha B. S. Mutagenesis and screening of Penicillium oxalicum (Dal 5) for enhancing cellulase production. Indian J Micribiol Res 2018;5(1):7-13 